\title{
The Relationships among Organizational Knowledge Sharing Practices, Employees' Learning Commitments, Employees' Adaptability, and Employees' Job Satisfaction: An Empirical Investigation of the Listed Manufacturing Companies in Jordan
}

\author{
Soud Almahamid \\ Al Hussein Bin Talal University, \\ Ma'an, Jordan \\ soud.almahamid@ahu.edu.jo
}

\author{
Arthur C. McAdams \\ Bridgeport University, \\ Bridgeport, CT, USA
}

Amcadams@bridgeport.edu

\author{
Taher Kalaldeh \\ Middle East University for Graduate Studies, Amman, Jordan \\ kanim99@yahoo.com
}

\begin{abstract}
To explore and empirically investigate the relationships among organizational knowledge sharing practices, employees' learning commitments, employees' adaptability, and employees' job satisfaction. A cross sectional survey as a method of data collection was adopted and the population of this study consists of the entire Listed Manufacturing Companies (91 companies) in Amman Stock Exchange. The results of data analysis suggest that the organizational knowledge sharing practices has taken place in the Jordanian manufacturing companies according to the perceptions of respondents. In addition, the results indicates that there is a significant statistical relationship between organizational knowledge sharing practices, employees learning commitments, employees' adaptability, and employees' job satisfaction. Finally, the results suggest that there is no difference in the evaluation of organizational knowledge sharing practices by research respondents in terms of demographic variables such as, gender, age, and level of education. This study has the limitations of the cross-sectional studies. In addition, it did not take into account if the possibility of any moderating variables that may strengthen or weaken the hypothesized relationships in this study. It enriches prior knowledge sharing theories by showing manufacturing managers the prac-

Material published as part of this publication, either on-line or in print, is copyrighted by the Informing Science Institute. Permission to make digital or paper copy of part or all of these works for personal or classroom use is granted without fee provided that the copies are not made or distributed for profit or commercial advantage AND that copies 1) bear this notice in full and 2) give the full citation on the first page. It is permissible to abstract these works so long as credit is given. To copy in all other cases or to republish or to post on a server or to redistribute to lists requires specific permission and payment of a fee. Contact 0HPublisher@InformingScience.org to request redistribution permission.

tical implications of organizational knowledge sharing practices. It also draws the attention of Jordanian manufacturing managers towards the role of knowledge sharing practices in ensuring a high level of employees' adaptability and facilitating employees' learning commitments to deal with dramatic, unpredicted, and unexpected environmental changes. Finally, it gives Jordanian managers an idea of how to in-
\end{abstract}


crease employees' job satisfaction by establishing knowledge sharing practices and ensuring ongoing learning process that prepare employees to think and react in new ways without panic.

Key words: knowledge sharing practices, employees' learning commitments, employees' adaptability, employees' job satisfaction.

\section{Introduction}

Today's business environment is characterized by fast, dramatic, and unexpected changes. Therefore, managers not only have to be high performers in the traditional sense, but also fast and adaptive learners (Karaevli \& Hall, 2006). Several new competencies are needed to cope in this new environment because business managers work under different circumstances and environments. Prior research indicates that an individual's adaptability and learning commitments enable business managers to manage and overcome many unexpected difficulties in a business environment. Perpetual changes in the workplace and daily business activities bring a need for using organizational knowledge sharing practices and an increase in demand for continuance learning. Since a manager's typical work requires adaptive responses to new environmental conditions, it has been asserted that only knowledge sharing and continuous learning behavior can lead to effective responses. A review of knowledge sharing literature reveals two knowledge sharing implications: individual learning commitments and individual adaptability. These are expected to improve individual competencies and then lead to individual job satisfaction. Individuals' competencies usually provide capital gains for both individuals and organizations. Because individuals have heterogeneous amounts of knowledge, skills, and capabilities that vary across organizations, it is important they are guided and coordinated effectively to improve organizational performance.

Three approaches are used to enhance employees' knowledge sharing within organizations:

- a technology-based approach in which the technology is considered the facilitator of knowledge sharing practices within an organization;

- an incentive-based approach in which the monetary and non-monetary rewards promote knowledge sharing practices;

- and an organizational-based approach in which structure, processes, and management style simplify the application of knowledge sharing practices (Hsu, 2006).

Although the first and the second approach have received scrutinized testing, the implications of the third approach have been largely untested. This study investigates the third approach from the Jordanian manufacturing managers' perspectives. Although knowledge sharing has been considered an important goal in almost all types of organizations, it is still represents a concern for many employees. Usually, organizations mitigate these concerns by offering various incentives and rewards. In fact, effective organizational knowledge sharing practices prepare employees to share and accept new ideas and learn new ways of thinking, which leverages their knowledge and capabilities.

Nurturing a learning culture within organizational boundaries encourages employees to continually learn from each other (Becerra-Fernandez, Gonzalez, \& Sabherwal, 2004). Also, employees will adapt their information needs according to new changes in the business environment. Employees' commitment to learning and willingness to learn new knowledge and skills not only improve an organization's competitive advantage but also foster ongoing success (Tsai, Yen, Huang, \& Huang, 2007). Organizations seeking performance gains should consider dedicating a significant amount of effort toward fostering employees' learning and sharing behaviors. In spite of the growing interest in organizational knowledge sharing practices, its challenges, antecedents, and performance implications, there is still a dearth of empirical studies that investigate organiza- 
tional knowledge sharing practices implications such as individuals learning commitments, individuals' adaptability, and individuals' job satisfaction. Therefore, it appears that investigating this issue in more detail is worthwhile. Thus, this research investigates the relationships between three important and yet neglected organizational knowledge sharing practices implications: employees' learning commitments, employees' adaptability, and employees' job satisfaction.

\section{Motivations of This Study}

This study is motivated by the recommendations that have appeared in knowledge sharing literature (e.g., Becerra-Fernandez et al., 2004; Tsai et al., 2007). According to Becerra-Fernandez et al. (2004), knowledge management impacts organizations on four levels: processes, products, people, and performance. However, how organizational knowledge sharing impacts people - employees' learning commitments, employees' adaptability, and overall employees' job satisfaction - is still vague and ill-defined. So far, there have been no empirical studies that link knowledge sharing practices with employees learning commitments, employees' adaptability, and employees' job satisfaction. In fact, while knowledge sharing practices have received extensive examination in developed countries; it has received much less attention in developing countries, such as Jordan. Successful knowledge sharing practices in western countries are not necessarily the same as those in developing countries as the cultural issues and religion dogmas are totally different. In addition, this work has never been done in the Jordanian manufacturing context. Furthermore, this study attempts to extend the arguments of Becerra-Fernandez et al. (2004) to show how organizational knowledge sharing practices enhance employees' learning commitments, employees' adaptability, and employees' job satisfaction. Thus, the main assumption of this research is that effective organizational knowledge sharing practices leverage employees' learning commitments, employees' adaptability, and improve overall employees' job satisfaction. We believe these provide a base and justification for examining empirically the relationship between organizational knowledge sharing practices, employees' learning commitments, employees' adaptability, and employees' job satisfaction. This analysis may help managers to fully understand the significance of organizational knowledge sharing practices in facilitating employees' learning commitments and employees' adaptability, and then, increasing employee' job satisfaction.

\section{The Objectives of this Study}

The objectives of this study can be expressed by the following research questions:

1. Do Jordanian manufacturing companies utilize organizational knowledge sharing practices?

2. What is the relationship between organizational knowledge sharing practices, employees' learning commitments, employees' adaptability, and employees' job satisfaction?

3. Are there any differences in the evaluation of knowledge sharing practices by Jordanian manufacturing managers that can be attributed to demographic variables such as, age, gender, and level of education?

This paper is organized as follows: Section 1 - Introduction, Section 2 - Literature Review, Section 3 -Design/Methodology, Section 4 - Findings/ Results, and Section 5 - Conclusion and practical Implications.

\section{Literature Review}

Here follows a review of the literature that describes the relationship among the constructs of this study. The literature is divided into subsections, as shown below: 


\section{Antecedents and Consequences of Knowledge Sharing}

In today's business environment, change is constant and multidimensional. New competitors, new potential customers, advanced new technology, and intense global competition alter or completely modify most industries in unexpected manners. To prosper, organizations should use this turbulent environment as an opportunity rather than a threat. Organizations need to adapt quickly to new conditions. Knowledge sharing is considered an important factor related to the ability of both employees and organizations to respond quickly to a changing business environment. Prior studies focus only on knowledge sharing antecedents or consequences (Du, Ai, \& Ren, 2007; Hsu, 2008; Hsu, Ju, Yen, \& Chang, 2007; Kuo \& Young, 2008; Law \& Ngai, 2008; Siemsen, Roth, \& Balasubramanian, 2008; Yang, 2007, 2008, 2009). Knowledge sharing has been cited as a precondition of organization competitiveness (Du et al., 2007; Hsu, 2008; Kearns \& Lederer, 2003). In other words, the assumption here is knowledge sharing can help organizations to outperform direct competitors. Meanwhile, Parker and Kyj (2006) highlight the importance of revealing normally private information through the budgeting process to gain competitive advantage. Although top management believes that information technology enables knowledge sharing practices; the truth is the willingness and attitudes of individuals is the key factor (Yang, 2008).

Michailova and Husted (2003) propose that cultural factors can also lead to significant failure of knowledge sharing and increased individuals' reluctance to share their knowledge in an organizational context. Because sharing is a contextual factor, the design and availability of reward systems becomes crucial (Lee \& Ahn, 2006). Although there is a significant body of research that has investigated knowledge sharing aspects, there is no widely accepted definition for knowledge sharing. For example, Nonaka (1991) and Rowley (2000) broadly define knowledge management as a process through which useful information is identified and collected from different sources (i.e. the process of knowledge acquisition that enables employees to retrieve and processing organizational related knowledge; the process of organizing knowledge that invents and applies knowledge properly; the process of leveraging and circulating knowledge through all organizational levels, and the process of storing and sharing knowledge in organizational databases to build an organizational memory). Others, Bartol and Srivastava (2002) define knowledge sharing as an action in which employees diffuse relevant information to others across the organization. According to Bock \& Kim (2002), knowledge sharing is considered the cornerstone of knowledge management. Also, Inkpen (2000) asserts that: "unless individual knowledge is shared throughout an organization, the knowledge will have a limited impact on organizational effect" (p.124). Lin (2008) describes this in operational terms: "the exchange of knowledge and sharing of experiences among different organizational units." However, collecting, storing, processing, and retrieving knowledge is out the scope of this study.

A review of recent literature shows that knowledge sharing is fragmented around three strains (Chiu, Hsu, \& Wang, 2006; Lin, 2008): Theory - Several theories have been used to explain how and why knowledge sharing should be achieved within organizations (i.e., Resources-Based Theory, Transaction Cost Theory, and Social Capital Theory). Methodology - Multiple methods and tools are used to facilitate knowledge sharing (i.e., System Planning, System Reengineering, and Communication Systems), and Sharing - sharing within and between organizations (i.e., Interdepartment, Inter-organization, Inter-network, and Inter-group). The goal of knowledge sharing in the three strands is to improve organizations competitiveness. Although the first two strands are very important to facilitate knowledge sharing, the final decision on whether to share or not is held by employees and is determined by the kinds of rewards they expect or require. Therefore, reward systems should target individuals and groups alike in a consistent manner. Lee and Ahn (2006) develop a model that links knowledge sharing to two types of reward systems: Individualbased reward systems which are based on individual contribution of valuable knowledge, and group-based reward systems which are based on the whole group contribution in knowledge shar- 
ing that improves organizational performance. Their results indicate that an individual-based system is more efficient than group-based systems. In the group-based systems, knowledge workers are less likely to share their knowledge. However, Siemsen et al. (2008) utilize a well established motivational framework that includes opportunity and ability to explain employees' knowledge sharing behaviors. Their results suggested that a constraining-factor model acts as a new perspective and can explain employees' knowledge sharing behaviors by demonstrating that motivation does not always improve knowledge sharing but is contingent upon other conditions. Another related study, Kuo \& Young (2008) suggested a research model based on "Theory of Reasoned Action" and "Theory of Planned Behavior" that predicts that knowledge sharing intention behavior is a function of attitude, subjective norm, and perceived behavior control. They argued that self-efficacy directly predicts knowledge sharing behavior. Furthermore, Yang (2008) extends this notion further and states that individual attitudes toward learning, sharing, and storing have significant influence on organizational knowledge sharing. His results confirmed that individual attitudes toward learning and sharing impact organizational knowledge sharing. And finally, in a qualitative study in manufacturing companies in Taiwan, Hsu (2006) suggests three organizational practices that enhance employees' tendencies to share their knowledge: continuous company-wide learning initiatives, performance management systems, and information discloser to create a sharing climate.

Despite the fact that knowledge sharing is needed in all types of organizations, many contextual factors prevent nurturing knowledge sharing practices. For example, Lin (2008) suggests that organizational structure characteristics, organizational culture, and organizational interaction have strong motivational power for knowledge sharing. Likewise, Yang (2007) proposes that leadership roles (i.e. facilitator, mentor, and innovator) and collaborative culture are strongly correlated with knowledge sharing. Employees are often inclined to hoard their knowledge even when a collaborative culture is established and informal relationships exist (Michailova and Husted, 2003). According to Garfield (2006), there are 10 reasons that explain why people don't share their knowledge: they don't know why they should do it; they don't know how to do it; they don't know what they are supposed to do; they think the recommended way will not work; they think their way is better; they think something else is more important; there is no positive consequence to them for doing it; they think they are doing it; they are rewarded for not doing it, and they are punished for doing it.

Knowledge sharing is not limited to traditional organizational settings but it may exist in virtual organizations and communities. Hsu et al. (2007) show how the trust, self-efficacy, and outcome expectations in communities of practices influence the willingness of employees to share their knowledge. The results indicate that self-efficacy has both direct and indirect effects on knowledge sharing behavior. In addition, the personal outcome expectations have significant influence on knowledge sharing behavior. Their study suggests that economy-based trust and informationbased trust have to be established before developing identification-based trust to ensure an environment marked by overall mutual trust. In fact, there are two ways employees share their knowledge: formal and informal. According to Zahra, Neubaum, and Larrañeta (2007), exploring the relationship between knowledge sharing and technological capabilities to test the moderating role of family involvement is worthy empirical investigation. Their results show that knowledge sharing practices can occur formally and informally. In addition, while family ties facilitate formal and informal sharing of knowledge within family firms; jealousies, rivalries, and concentration of power restrain sharing behavior. Furthermore, whereas formal and informal knowledge sharing practices strengthen families' firms' technological capabilities, the relationship between informal knowledge sharing and technological capabilities is enhanced when the top managers have family members. However, despite the bulk of literature in the last few years on knowledge management and knowledge sharing; a deep understanding of organizational knowledge sharing practices and its impacts on organizational issues is still needed and much more research should be done. 
Becerra-Fernandez et al. (2004) argue that "knowledge management impacts employees in several ways: first, knowledge management can facilitate their learning (from each other and as well as from external sources). This learning allows the organization to be constantly growing and changing in response to the market and technology changes. Second, knowledge management also causes employees to be more flexible, and enhance their job satisfaction. This is largely because of their enhanced ability to learn solutions to business problems that worked in the past, as well did not work" p52. These theoretical arguments are acceptable to some extent, but they lack empirical evidence. It clarifies the role of knowledge management in a general view, despite the fact that knowledge management has several processes (discovering, capturing, sharing, and application). We can extend and scrutinize these arguments and argue that knowledge sharing practices rather than knowledge management enhance employees' learning commitments, employees' adaptability, and overall employees' job satisfaction.

\section{Knowledge Sharing Practices and Learning Commitments}

It has been argued that nurturing a knowledge sharing culture and establishing the right climate for knowledge sharing is a fundamental issue for successful organizational performance that maintains competitive advantage. However, one of the most critical decisions employees usually face is whether or not to share knowledge. This decision is often determined by reflecting on several questions: What to share? And with whom should I share? What are the real benefits for me to share? Do the employees with whom I share going to share their knowledge with me? Does sharing improve my knowledge and skills? Prior research has gone further to determine if there is a significant relationship between knowledge sharing and organizational performance (Du et al., 2007). Similarly, while Hsu (2008) suggests that knowledge sharing practices are considered the facilitating factor for improving organizational performance through human capital, Law and Ngai (2008) acknowledge that even though knowledge sharing may affect organizational performance, it is also important to examine the relationships between knowledge sharing and learning behaviors, business process improvements, and product and service offerings to fully understand the factors that effect organizational performance. Their results revealed that knowledge sharing and learning behaviors are positively related to business process improvement and product and service offerings. In addition, business process improvement and product and service offerings are associated with organizational performance.

This result indicates that knowledge sharing may indirectly influence knowledge sharing through other intervening variables such as, human capital, learning commitments, and adaptability. Therefore, we argue that knowledge sharing practices play a significant role in improving employees' learning abilities, employees' adaptability, and employees' job satisfaction. The interplay between these constructs should be understood as a continuous process rather than dichotomous constructs. This indicates that employees in organizations possibly get various levels of knowledge sharing that creates multiple levels of adaptability and job satisfaction. So far, prior studies fail to make a clear distinction as to whether learning improves adaptability or adaptability facilitates learning. We argue that there is a mutual relationship between individual learning behavior and adaptability. Thus, a high level of knowledge sharing may lead to a high level of learning commitments, which in turn leverages employees' job satisfaction. However, these arguments deserve further empirical proof and theoretical advancement. Building on the above arguments; we believe that if employees have access to the latest knowledge, information, and skills, their learning behaviors are enriched and enhanced effectively. In a rigid qualitative and quantitative data analysis of motivations for employees' learning commitment in the postdownsizing era, Tsai et al.(2007) revealed that "family relationships" and "interpersonal relationships" are the most important factors that influenced employees' learning commitment in the job satisfaction construct. Thus, when more attention is paid to employees' interpersonal relationships with colleagues and family relationships, they will gain more knowledge and learn many 
new skills. These interpersonal relationships with family and colleagues are part of knowledge sharing activity that is also called "socialization." Paulsson, Ivergard, and Hunt (2005) argued that when workers control their learning process the competence development is easily provoked. Work tasks are therefore executed smoothly and free of stress. However, the individual learning process is most likely voluntarily rather compulsory. Thus, the biggest challenge is fostering willingness to learn new knowledge and skills within all organizational levels to enhance competitiveness and innovativeness. In the marketing context, group innovativeness increases dramatically when the group members are encouraged to learn and develop, and are able to influence group decisions (Hurley \& Hult, 1998). They argued that learning is antecedent to innovativeness. Therefore, encouraging employees' to learn new knowledge and skills would increase their learning commitments and adaptability.

\section{Knowledge Sharing Practices and Adaptability}

Various concepts, abstracts, and models are used in the literature to describe the construct of adaptability, such as role flexibility (Murphy \& Jackson, 1999), adaptive performance (Hesketh \& Neal, 1999; Pulakos, Arad, Donovan, M., Plamondon, 2000), adaptive workforce (Pulakos, Dorsey, White, 2006), adaptive capacity (Moyers \& Coleman, 2004), and agility (Sherehiy, Karawowski, \& Layer, 2007). While Hartline \& Ferrell (1996) define employees' adaptability as "the ability of contact employees to adjust their behaviour to interpersonal demands of the service counter" (p: 55), Ployhart and Bliese (2006) state that an individual's adaptability represents "an individual ability, skills, disposition, willingness, and/or innovation, to change or to fit different tasks, social, and environmental features" (p. 13). According to Savickas (2005), adaptability involves adjusting to vocational development tasks, occupational transitions, and personal traumas by solving problems that are usually unfamiliar, often ill-defined, and always complex" (p. 51). More than that, Park and Holloway (2003) argue that there is still much more research needed to investigate the relationships between adaptability behavior and employees' job satisfaction. Their results highlight the fact that adaptability contributes to sales performance and job satisfaction. Furthermore, Paulsson et al. (2005) assert that adaptability enhances employees' competencies. In fact, being adaptive and a fast learner becomes the most critical factor that determines a strong performer (Karaevli \& Hall, 2006).

Adaptability is a function of interaction among the worker's personal characteristics that is related to age, the work tasks, and the task environment (Moyers \& Coleman, 2004). According to Moyers \& Coleman (2004), personal characteristics, work tasks, and environments represent occupational challenges especially for older worker's adaptive capacity. Adaptive capacity in that context refers to "whether the worker possesses the behavioral repertoire to act, possesses the ability to modify existing behaviors, or has the ability to produce new behaviors needed for achieving success and relative mastery" (p. 73). One of the personal characteristics is flexibility, that is, how flexible thinking and flexible personality create new ideas and new knowledge. In terms of improvement of flexibility at the individual level, complementary approaches could be used that include: altering the work organization, changing a person's rigid attitudes and developing a person's flexibility. By initiating loosely established boundaries between individual workers and facilitating the climate for them to work together, an organization can create a flexible team comprised of independent individuals. This, in turn, represents an opportunity to explore unstructured or semi-structured problems from different angles. According to Georgsdottir and Getz (2004), organizations can adopt the following approaches to enhance flexibility: On the individual level of innovator - flexibility to drive innovation can be improved by altering the work organization, changing a person's rigid attitudes and developing a person's flexibility. On the audience level for ideas - flexibility for innovation can be improved through altering the organizational structure, changing managers' rigid attitudes and developing flexibility in management. The personal flexibility represents a significant part of individual adaptability. However, Tuomi- 
nen, Rajala, and Moller (2004) examined the organizational adaptability in terms of technology mode, market focus, and organizational design, and link them to the level of innovativeness in industrial manufacturing companies. Their results indicate that the components of organizational adaptability have a strong relationship with the level of innovativeness. The seminal book of Burke, Pierce, and Salas (2006) shows that the adaptability can be achieved on three levels: individual, team, and organization. This study focuses on the individual adaptability that represents the solid base for team and organizational adaptability and is directly affected by the willingness of the individual to interact with other employees, which is also called "knowledge sharing". On the individual level, Pulakos et al. (2006) argued that there is a need for workers to be more adaptable, versatile, and tolerant to do their work tasks efficiently and effectively especially under unexpected and unpredicted environmental changes. This need will be significant as long as change continues in a constant manner. Thus, it can be assumed that the only way of earning new skills and knowledge in a cost-effective manner will be through knowledge sharing. The logic is that knowledge sharing facilitates individual adaptability by providing individuals with new skills and knowledge that fit with the new environmental conditions.

\section{The Link between Knowledge Sharing, Employees' Learning Commitments, Employees' Adaptability, and Employees' Job Satisfaction}

It is more likely that employees who learn new knowledge and skills will become more adaptable and responsive to changes in the business environment. Therefore, the stress that is caused by internal or external changes of business conditions which require new skills and knowledge become less likely to occur. Thus, employees will do their job more competently and completely as they successfully transition from their previous rigid skill and mindset to the new model that emphasizes continuous adaptability. However, Kameda \& Nakanishi (2003) challenge the wisdom that states "social/cultural learning increase human adaptability through uncertainty reduction". By using various simulation steps, their results indicate that at some point the agent has to switch between costly individual learning by trial and error and free riding or copying other individual behavior.

We argue that employees' confidence and self-efficacy are more likely to be enhanced and increased by increasing knowledge and skills acquisition. Thus, their market value will also be increased within this environment as compared to those organizations with non-knowledge sharing. In this case, employees who are willing to learn or acquire new knowledge have gained the ability to solve semi-structured and unstructured business problems. In turn, employees stay up to date with the latest knowledge and skills that enable them to deal with the continual environmental changes.

Prior research has indicated that when employees are highly satisfied with their job, they are more creative, innovative, and willing to do their job effectively. Whereas, when employees are unsatisfied with their job, their moral and willingness to implement required tasks is very low. Although the current research benefits from prior studies in all its stages, these studies do not make a clear link between knowledge sharing practices and its implications, such as employees' adaptability, employees' learning commitments, and employees' job satisfaction. In addition, the current literature ignores the importance of knowledge sharing in enhancing an employee's continuance learning and adaptability but rather focuses on contextual factors that impact knowledge sharing or facilitating individual knowledge sharing. Therefore, it is logical to deduce that if a continuous learning process has been established, employee adaptability would be guaranteed, and improved employee job satisfaction would be also ensured. From the above discussions, it seems that understanding the relationships between organizational knowledge sharing practices, employees' adaptability, employees' learning behaviors, and employees' job satisfaction is still in 
its infancy. Therefore, more theoretical and empirical explanations are needed. In fact, it is plausible to assume that organizational knowledge sharing to be considered as a catalyst of a dynamic employees' adaptability, and employees' learning commitments which in turns, increase over all employees' job satisfaction especially under accelerated technological developments and environmental changes, but this logic obviously lack of empirical root. This research tries to fill this void in the literature and make significant contributions to the prior theories of knowledge sharing.

\section{Contributions of this Research}

This research contributes to the following domains:

1. In making links between knowledge sharing practices, employees' learning commitments, employees' adaptability, and employees' job satisfaction. To the best of our knowledge, this work has never been done before in a Jordanian manufacturing sector context or even in the Middle East region.

2. In extending some of the theoretical ideas of Becerra-Fernandez (2004) by empirically investigating the validity of these ideas in a manufacturing context in Jordan.

3. In providing solid theoretical arguments that can be easily used as a foundation for empirical studies in different context (i.e. service sector, project team, and community of practice).

4. In expanding extant theories of knowledge sharing in a context that is not well represented in the current literature.

5. In presenting the view point of Jordanian manufacturing managers toward knowledge sharing practices and its implications as there is not abundant research that gathers manufacturing managers' perceptions toward knowledge sharing practices.

\section{Design/Methodology}

A positivistic methodology is adopted because of the need for quantitative data to satisfy the objectives of the research and the need for a large sample to carry out the data analysis. In addition, there is a need to examine the hypothesized relationships included in the research model depicted in Figure 1. The model examines the relationship between organizational knowledge sharing practices [OKS], employees' learning commitments [ELC], employees' adaptability [EAD], and employees' job satisfaction [EJS]. The model is constructed based on similar research models that appear in knowledge sharing literature (Becerra-Fernandez et al., 2004; Law \& Ngai, 2008). The related literature has been reviewed precisely to ensure the inclusion of implications of knowledge sharing practices that have not been investigated by prior studies.

This research intends to explore the relationships between organizational knowledge sharing practices, employees' learning commitments, employees' adaptability, and employees' job satisfaction. In addition, it seeks to find any differences in the evaluation of knowledge sharing practices by Jordanian manufacturing managers that can be attributed to the demographic variables such as: gender, age, and level of education. To collect the relevant data from the target population, a questionnaire survey was constructed based on prior tested and validated instruments in the literature. Minor modifications were done to make prior measures suit the Jordanian manufacturing context. The items for measuring organizational knowledge sharing practices were adapted from Hsu (2008). Seven items were used to measure organizational knowledge sharing practices. Items for measuring employees learning commitments were adapted from Tsai et al. (2007). 


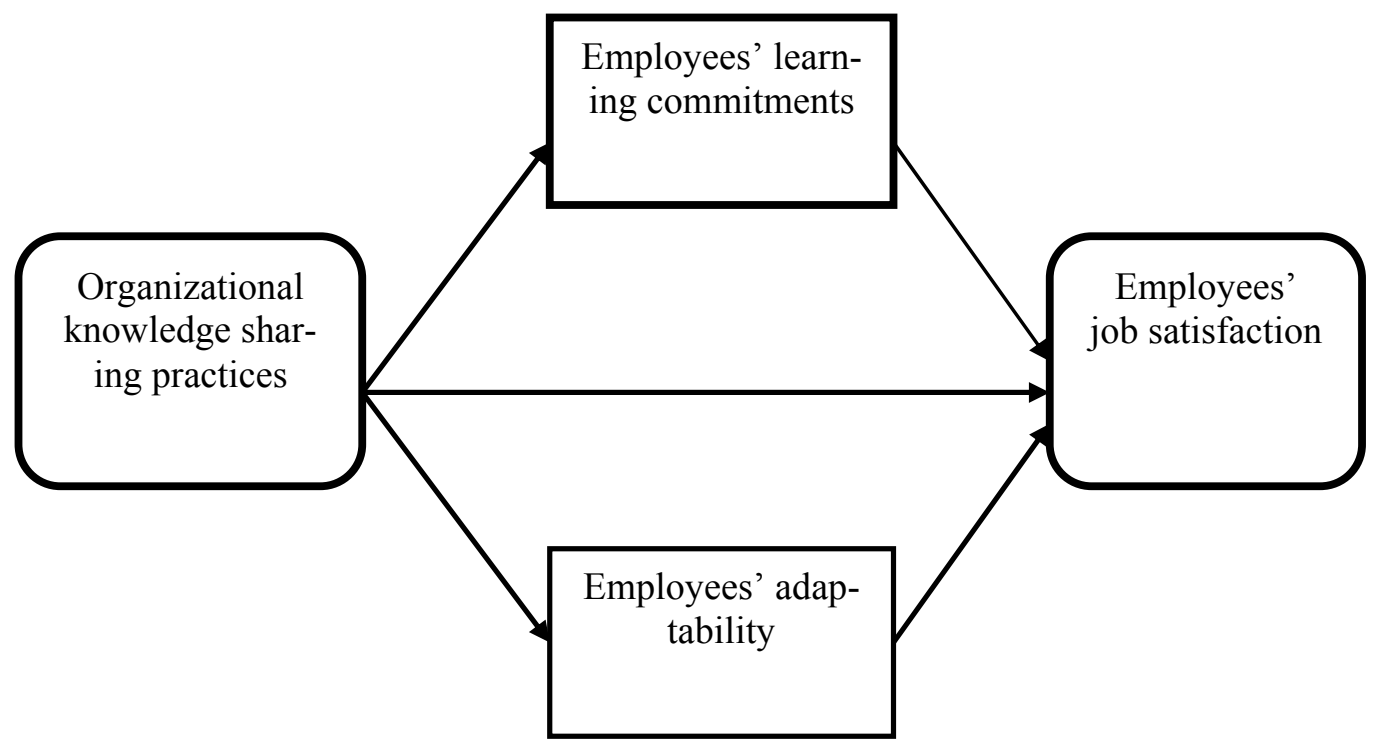

Figure 1. Research model

Participants were asked to rate the following statements: I am willing to spend extra time taking part in the internal and external training courses provided by the firm; I am eager to learn more specific knowledge and skills to achieve job goals; I believe that all learning opportunities are advantageous to me; I believe that all learning opportunities are advantageous to the firm, and To me, being able to learn constantly is very important. The items for measuring employees' adaptability were adapted from (Ployhart \& Bliese, 2006; Pulakos et al. 2000). Because the employees' adaptability is a multidimensional construct, the following dimensions are considered: Crisis adaptability, Cultural adaptability, Physical work adaptability, Uncertainty adaptability, Creativity adaptability, Interpersonal adaptability, Work-stress adaptability, and Learning adaptability. These dimensions measured by 55 items $(7,5,9,9,5,7,5,9)$ respectively. The items for measuring employees' job satisfaction were adapted from Vieira (2005). Each item of the questionnaire was anchored on a scale of 1 to 5 ranging from Strongly Disagree to Strongly Agree. For details see the Appendix.

The questionnaire was originally designed in English and then translated into Arabic. Afterwards, the Arabic version was checked by experts in knowledge sharing domain to ensure there was no loss of meaning during the translation process. High level of validity was ensured through extensive revision by experts and consultation of prior tested and validated instruments. Based on the feedback the researchers received from the reviewers, any question that caused confusion or was deemed potentially difficult to understand was dropped and replaced by new understandable one. Because the target population of this study is to some extent small, a decision was made to circulate the questionnaire to the entire Listed Manufacturing Companies in Amman Stock Exchange (91 companies). This population was targeted because it represents medium to large size companies which are expected to establish knowledge sharing practices in a wide-scale. In addition, it is expected to represent the industrial sector in general and to be more relevant and clearly reflect the research constructs. The questionnaire was accompanied by a cover letter explaining the research objectives and providing a guideline for completing the questionnaire. Each company in the research population was given three questionnaires, which were delivered to the general manager who was then asked to circulate the questionnaires to those managers that he believed were the most qualified to answer the research questionnaire. In total, 273 questionnaires were circu- 
lated to the targeted population. Out of 273 questionnaires we received 160 completed questionnaires. This represents a response rate nearly $59 \%$ which is quite suitable for this type of study.

From the research model in Figure (1), the null hypotheses can be derived as shown in Table (1). A cross-sectional data approach was used to test these hypotheses and is generally considered the most appropriate method for investigating this type of phenomenon. The philosophy of a crosssectional approach is to study a particular phenomenon at a particular time. Therefore, there is a need for a large sample to carry out advanced data analysis to ensure the research results are generalizable. A questionnaire was utilized to collect relevant data from the target population. The detailed survey proved to be a good tool for probing the beliefs and attitudes of employees toward knowledge sharing practices and its organizational and individual implications (Du et al. 2007; Hsu, 2008; Yang, 2007, 2008). It is not however such a good method for studying the process of knowledge sharing in an individual organization. Descriptive statistics and advance statistical techniques were used to test the research hypothesis.

\section{Table 1: Research hypothesis}

\begin{tabular}{llc}
\hline Null Hypothesis & $\begin{array}{l}\text { Construct } \\
\text { Hyp: Jordanian manufacturing companies do not practice or- } \\
\text { ganizational knowledge sharing. }\end{array}$ & $\begin{array}{c}\text { Organizational } \\
\text { Knowledge } \\
\text { Sharing prac- } \\
\text { tices }\end{array}$ \\
\hline Hypothesis 2 & $\begin{array}{l}\text { H0: There is no relationship between organizational knowl- } \\
\text { edge sharing practices and employees' learning commit- } \\
\text { ments. }\end{array}$ & $\begin{array}{c}\text { Employee' } \\
\text { Learning } \\
\text { commitments }\end{array}$ \\
\hline Hypothesis 3 & $\begin{array}{l}\text { H0: There is no relationship between organizational knowl- } \\
\text { edge sharing practices and employees adaptability. }\end{array}$ & $\begin{array}{l}\text { Employees' } \\
\text { Adaptability }\end{array}$ \\
\hline Hypothesis 4 & $\begin{array}{l}\text { H0: There is no relationship between organizational knowl- } \\
\text { edge sharing, employees' learning commitments, employees' } \\
\text { adaptability and employees' job satisfaction. }\end{array}$ & $\begin{array}{c}\text { Job satisfac- } \\
\text { tion }\end{array}$ \\
\hline Hypothesis 5 5 & $\begin{array}{l}\text { H0: There is no difference in the knowledge sharing prac- } \\
\text { tices evaluation by employees that can be attributed to demo- } \\
\text { graphic variables such as, gender, age, and level of educa- } \\
\text { tion. }\end{array}$ & $\begin{array}{c}\text { Demographic } \\
\text { variables }\end{array}$ \\
\hline
\end{tabular}

\section{Findings/Results}

A reliability test was carried out using Cronbach's alpha, which measures the internal consistency of research constructs. The recommended minimum acceptable limit of reliability - "alpha" - for exploratory study is 0.60 (Hair, Tatham, Black, Babin, \& Anderson, 2009) The results of $\alpha$ - values for all the research constructs [organizational knowledge sharing practices, employees' learning commitments, employees' adaptability, and employees' job satisfaction] are above the recommended values (See Table 2 ). Thus, it can be concluded that the scale has a high level of internal consistency and reliability which is in line with the recommendation of other scholars (Hsu, 2008). In other words, the items that are used in the questionnaire measure what they are intended to measure. Results of the Kolmogrov-Smirnov test on this research demonstrate that the answers 
from respondents are normally distributed (Asymp.sig. 2-tailed $<.05$ ), and therefore, the data are valid for further analysis.

Table 2: Cronbach's Alpha of research constructs

\begin{tabular}{|l|c|c|}
\hline \multicolumn{1}{c|}{ Research constructs } & Number of items & Cronbach's Alpha \\
\hline $\begin{array}{c}\text { Organizational Knowl- } \\
\text { edge sharing practices } \\
\begin{array}{c}\text { Employees Learning } \\
\text { Commitments }\end{array}\end{array}$ & 7 & .864 \\
\hline $\begin{array}{c}\text { Employees } \text { Adaptability } \\
\text { Dimensions }\end{array}$ & Number of items & Cronbach's Alpha \\
\hline $\begin{array}{c}\text { Crisis adaptability } \\
\text { Cultural adaptability }\end{array}$ & 6 & $\mathbf{. 8 5 5}$ \\
\hline Physical work adaptability & 5 & $\mathbf{8 0 8}$ \\
\hline Uncertainty adaptability & 9 & $\mathbf{. 6 5 1}$ \\
\hline Creativity adaptability & 9 & $\mathbf{. 5 9 8}$ \\
\hline Interpersonal adaptability & 5 & $\mathbf{8 1 3}$ \\
\hline Learning adaptability & 7 & $\mathbf{. 9 0 0}$ \\
\hline Work stress adaptability & 9 & $\mathbf{. 0 0 1}$ \\
\hline $\begin{array}{l}\text { Employees' Job satisfac- } \\
\text { tion }\end{array}$ & 5 & $\mathbf{. 6 6 7}$ \\
\hline
\end{tabular}

\section{Descriptive Statistics Results}

The first section of the questionnaire collects information about the respondents' background. The research sample (Table 3) consists of 108 males (approximately two-thirds: 67.5\%) and 52 females (nearly one-third: 32.5\%) and represents all types of manufacturing companies (Mining \& Extraction industries; Engineering and Construction; Electrical industries; Textile, Leather \& Clothing; Glass \& Ceramic industries; Chemical industries; Paper \& Cardboard industries; Printing \& Packaging; Food \& Beverages; and Tobacco \& Cigarettes). The majority of the respondents $(78.1 \%)$ are in the age range from 25 to 45 , which suggests that they have a considerable amount of knowledge especially since education is compulsory until the end of secondary school. Therefore, it is possible that these respondents will be willing to share their knowledge more than old-age employees. Also, they represent a good source of information to evaluate organizational practices such as their willingness to share knowledge as compared to non-educated employees. The respondents are distributed by education level as follows: $33.1 \%$ had less than secondary school, $30 \%$ had secondary school; $35 \%$ achieved a bachelor's degree, $1.2 \%$ earned a graduate (master's degree) and only .6\% held a PhD, which indicates that this sample represents highly educated respondents. 
Table 3: Distribution of research respondents according to demographic variables

\begin{tabular}{|c|l|c|c|}
\hline Variable name & Variable interval & Respondents number & Percentage \\
\hline \multirow{4}{*}{ Gender } & Male & 108 & 67.5 \\
\cline { 2 - 4 } & Female & 52 & 32.5 \\
\hline \multirow{4}{*}{ Age } & $18-24$ Years & 16 & 10.0 \\
\cline { 2 - 4 } & $25-31$ Years & 41 & 25.6 \\
\cline { 2 - 4 } & $32-38$ Years & 49 & 30.6 \\
\cline { 2 - 4 } $\begin{array}{c}\text { Level of educa- } \\
\text { tion }\end{array}$ & Mor & 35 & 21.9 \\
\cline { 2 - 4 } & $\begin{array}{l}\text { Less than 45 } \\
\text { dary School Secon- }\end{array}$ & 19 & 11.9 \\
\cline { 2 - 4 } & Secondary School & 53 & 33.1 \\
\cline { 2 - 4 } & College Certificate & 48 & 30.0 \\
\cline { 2 - 4 } & Bachelor's Degree & 56 & 0.0 \\
\cline { 2 - 4 } & Master's Degree & 2 & 0.6 \\
\cline { 2 - 4 } & PhD Degree & 1 & 1.2 \\
\hline
\end{tabular}

Descriptive statistics were determined to be most appropriate for testing the first hypothesis (H1). As it is stated, Jordanian manufacturing companies do not practice organizational knowledge sharing. It is important to test the perceptions of manufacturing managers, and the only way to measure this is through their levels of agreement with the items that relate to the organizational knowledge sharing practices within organizations context. The average response for each of the organizational knowledge sharing practices items is greater than the midpoint (3) of the Likert scale (see Table 4). This indicates that the respondents show a high level of agreement since their answers range between agree and strongly agree. In other words, the managers of the Jordanian manufacturing companies believe that their organizations have established a base for organizational knowledge sharing practices. Although all the average items of organizational knowledge sharing practices are above the midpoint, there is one exception in OKS6 (My company offers incentives to encourage knowledge sharing). The explanation for this can be explained as follows: although the manufacturing companies dedicate significant effort to facilitate organizational knowledge sharing practices, they are unwilling to offer incentives to employees as a way to increase employees' willingness to share knowledge. This is because Jordanian manufacturing managers believe that the monetary incentives can create jealousy between employees and will negatively impact knowledge sharing.

Table 4: Descriptive statistics of knowledge sharing practices.

\begin{tabular}{c|cc}
\hline $\begin{array}{c}\text { Knowledge shar- } \\
\text { ing practices }\end{array}$ & Mean & Std. Deviation \\
\hline OKS1 & 3.4250 & 1 \\
OKS2 & 3.2938 & 1.38544 \\
OKS3 & 3.1812 & 1.36383 \\
OKS4 & 3.4438 & 1.20140 \\
OKS5 & 3.3562 & 1.17279 \\
OKS6 & 2.9187 & 1.39167 \\
OKS7 & 3.5563 & 1.18559 \\
\hline
\end{tabular}




\section{Correlations and Regressions Results}

To test hypothesis $2,3,4$, and 5 , a correlation analysis was used to examine the strength of the relationships between independent variables: organizational knowledge sharing practices, employees' learning commitments, employees' adaptability, and the dependent variable: employees' job satisfaction. The correlation analysis allows testing the strength of relationships between several independent variables and one dependent variable, which is the case in this study. Therefore, correlation analysis is the most suitable method for testing research hypothesis numbers $(\mathrm{H} 2, \mathrm{H} 3$, $\mathrm{H} 4$, and H5). The results of correlation analysis (see Table 5 ) shows that the relationships between organizational knowledge sharing practices, employees' learning behaviors, employees' adaptability, and employees' job satisfaction are significant on .01 level of significant (PValue $=.000<.01)$. This indicates that there is a relationship between organizational knowledge sharing practices, employees' learning behaviors, employees' adaptability, and employees' job satisfaction. Thus, further analysis becomes possible to examine the amount of variance in the dependent variable that can be explained by independent variables.

Table 5: The correlation between organizational knowledge sharing practices, employees' learning commitments, employees' adaptability and employees' job satisfaction

\begin{tabular}{|c|c|c|c|c|c|}
\hline \multicolumn{6}{|c|}{ Correlations } \\
\hline & & $\mathrm{X} 1$ & $\mathrm{X} 2$ & $\mathrm{X} 3$ & $\mathrm{Y}$ \\
\hline \multirow{3}{*}{$\begin{array}{l}\text { Organizational } \\
\text { Knowledge shar- } \\
\text { ing } \\
\text { (X1) }\end{array}$} & $\begin{array}{l}\text { Pearson Correla- } \\
\text { tion }\end{array}$ & 1 & $.185^{*}$ & $.271^{* *}$ & $.413^{* *}$ \\
\hline & Sig. (2-tailed) & & .019 & .001 & .000 \\
\hline & $\mathrm{N}$ & 160 & 160 & 160 & 160 \\
\hline \multirow{3}{*}{$\begin{array}{l}\text { Employees } \\
\text { Learning com- } \\
\text { mitments } \\
(\mathrm{X} 2)\end{array}$} & $\begin{array}{l}\text { Pearson Correla- } \\
\text { tion }\end{array}$ & $.185^{*}$ & 1 & $.416^{* *}$ & $.388^{* *}$ \\
\hline & Sig. (2-tailed) & .019 & & .000 & .000 \\
\hline & $\mathrm{N}$ & 160 & 160 & 160 & 160 \\
\hline \multirow[t]{3}{*}{$\begin{array}{l}\text { Employees } \\
\text { Adaptability (X3) }\end{array}$} & $\begin{array}{l}\text { Pearson Correla- } \\
\text { tion }\end{array}$ & $.271^{* *}$ & $.416^{* *}$ & 1 & $.469^{* *}$ \\
\hline & Sig. (2-tailed) & .001 & .000 & & .000 \\
\hline & $\mathrm{N}$ & 160 & 160 & 160 & 160 \\
\hline \multirow{3}{*}{$\begin{array}{l}\text { Employees } \\
\text { Job satisfaction } \\
\text { (Y) }\end{array}$} & $\begin{array}{l}\text { Pearson Correla- } \\
\text { tion }\end{array}$ & $.413^{* *}$ & $.388^{* *}$ & $.469^{* *}$ & 1 \\
\hline & Sig. (2-tailed) & .000 & .000 & .000 & \\
\hline & $\mathrm{N}$ & 160 & 160 & 160 & 160 \\
\hline
\end{tabular}

*. Correlation is significant at the 0.05 level (2-tailed).

**. Correlation is significant at the 0.01 level (2-tailed).

For hypothesis 2, simple regression was carried out to test the relationship between organizational knowledge sharing practices and employees' learning commitments. The results in Table 6 show that organizational knowledge sharing practices are related to $(\mathrm{R}=0.185 \mathrm{P}<0.05)$ employees' learning commitments. This indicates there is a significant positive relationship between organ- 
izational knowledge sharing and employees' learning commitments. Thus, we reject the null hypothesis that assumed there is no significant relationship between organizational knowledge sharing and employees learning behaviors and we accept the alternative hypothesis.

Table 6: Regression analysis of relationship between organizational knowledge sharing practices and employees' learning commitments

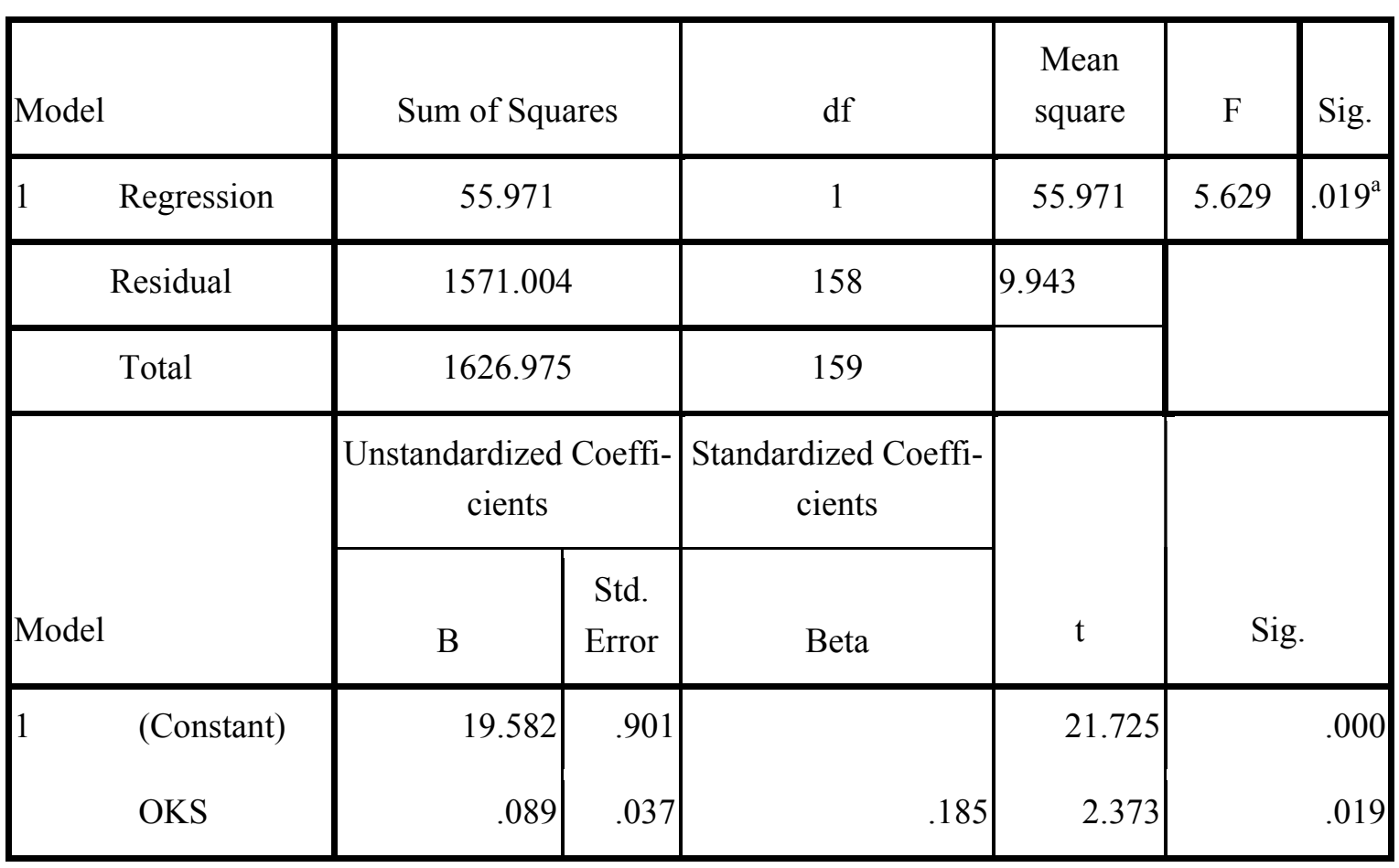

a. Dependent Variable: ELC

To test hypothesis 3 , simple regression was carried out to test the relationship between organizational knowledge sharing practices and employees' adaptability. The results in table (7) show that organizational knowledge sharing practices relate to $(\mathrm{R}=0.271 \mathrm{P}<0.05)$ employees' adaptability. This indicates that there is significant positive relationship between organizational knowledge sharing and employees adaptability. Therefore, we reject the null hypothesis that stated there is no relationship between organizational knowledge sharing and employees' adaptability and we accept the alternative hypothesis. The results in Tables 5, 6, and 7 that show positive relationships between independent variables and the dependent variable allowed us to use multiple regression analysis to explore further the relationship between the three independent variables "Organizational Knowledge Sharing Practices", "Employees' Learning commitments", "Employees Adaptability", and the dependent variable ("Employees' Job Satisfaction"). The multiple regression analysis shows how much of the variance in the dependent variable can be explained by independent variables. Multiple regressions often use known values of independent variables to predict the value of dependent variable. Table 8 shows that organizational knowledge sharing practices, employees' commitments, and employees' adaptability accounted for nearly $(\mathrm{R}=.59 \%)$ of the total variance in employees' job satisfaction, which is highly significant as indicated by $\mathrm{F}$ value, which is less than $.05(\mathrm{~F}=27.267, \mathrm{P}<.000)$. An examination of the $\mathrm{t}$-values indicates that organizational knowledge sharing practices, employees' learning commitments, and employees' adaptability were significantly related to employees' job satisfaction $(\mathrm{T}=4.331, \mathrm{P}$-value $=.000$; $\mathrm{T}=2.898, \mathrm{P}$-value $=.004 ; \mathrm{T}=4.158, \mathrm{P}$-value $=.000$ respectively) . 
Table 7: Regression analysis of the relationship between organizational knowledge sharing practices and employees adaptability

\begin{tabular}{|c|c|c|c|c|c|c|c|}
\hline \multicolumn{2}{|c|}{ Model } & \multicolumn{2}{|c|}{ Sum of Squares } & df & $\begin{array}{l}\text { Mean } \\
\text { Square }\end{array}$ & $\mathrm{F}$ & Sig. \\
\hline 1 & Regression & \multicolumn{2}{|c|}{5927.414} & 1 & 5927.414 & 12.484 & .001 \\
\hline & Residual & \multicolumn{2}{|c|}{75020.830} & 158 & 474.815 & & \\
\hline \multicolumn{2}{|r|}{ Total } & \multicolumn{2}{|c|}{80948.244} & 159 & & & \\
\hline \multirow{2}{*}{\multicolumn{2}{|c|}{ Model }} & \multicolumn{2}{|c|}{ Unstandardized Coefficients } & $\begin{array}{l}\text { Standardized } \\
\text { Coefficients }\end{array}$ & & \multirow{2}{*}{\multicolumn{2}{|c|}{ Sig. }} \\
\hline & & B & Std. Error & Beta & $\mathrm{t}$ & & \\
\hline \multirow[t]{2}{*}{1} & (Constant) & 181.919 & 6.229 & & 29.206 & & .000 \\
\hline & OKS & .913 & .258 & .271 & 3.533 & & .001 \\
\hline
\end{tabular}

$\mathrm{R}=0.271 \quad \mathrm{R}$ Square $=0.073 \quad$ Adjust $\mathrm{R}$ Square $=0.067$

Dependent Variable: EAD

Table 8: Regression Model of organizational knowledge sharing practices, employees' learning commitments, employees' adaptability, and employees' job satisfaction

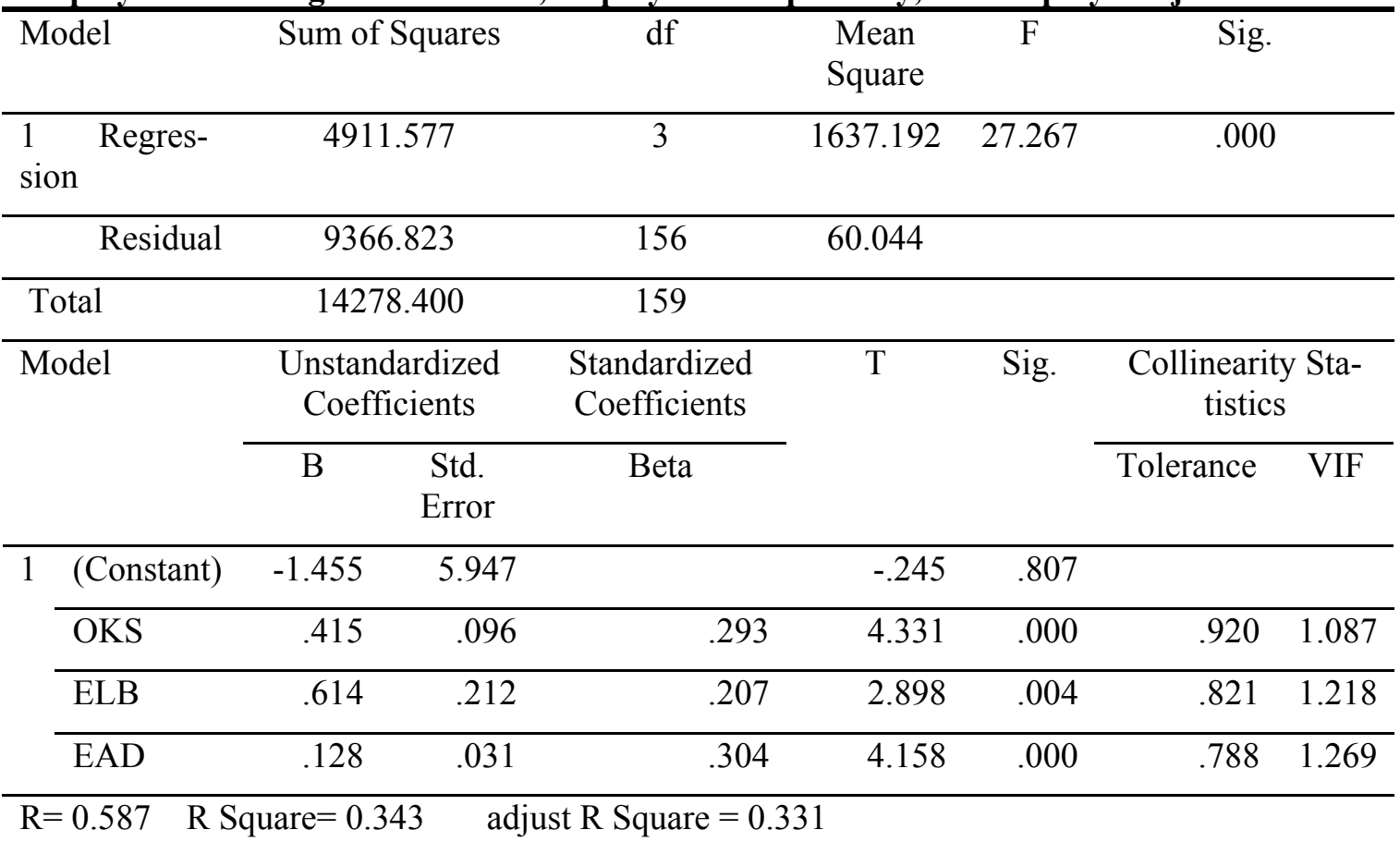

Dependent Variable: EJS 
Although this indicates that the independent variables are able to explain a significant amount of variance in dependent variable, there is room for other factors that may determine employees' job satisfaction (unexplained variance $0.41 \%$ ). To ensure there is no multi-colinearity between research variables, a co-linearity test was carried out [Tolerance and Variance Inflation Factor (VIF)]. Tolerance is the amount of variance in the dependent variable that is not explained by independent variables. A tolerance value less than (0.1) - which is not the case here - should be investigated further. The VIF statistics are below (10) and indicate no sign of a serious problem related to multi-collinearity (Yang, 2007).

Two statistical tests were performed to test hypothesis H5. First, an independent sample T-Test was used to examine if there are any differences between male and female employees in their evaluation of organizational knowledge sharing practices. Table 9 shows the results of the Levene's test with a P-value and an F value of .039 , which is $(<0.05)$ greater than 0.05 . (F is not significant). When the Equal variance is not assumed and the test is not significant, we should assume equal variance. The equal variance line shows that the $T$ value $(D F=158)$ is $(-7.02757)$ and the two tail P-value is $(0.483)$. Therefore, the P-value for a one-tail test is $=0.2415$. In this case, $\mathrm{T}$ is not significant at the .05 level. This indicates that there are no differences between males and females respondents in terms of the evaluation of organizational knowledge sharing practices in the Jordanian manufacturing context.

Table 9: The independent sample T test

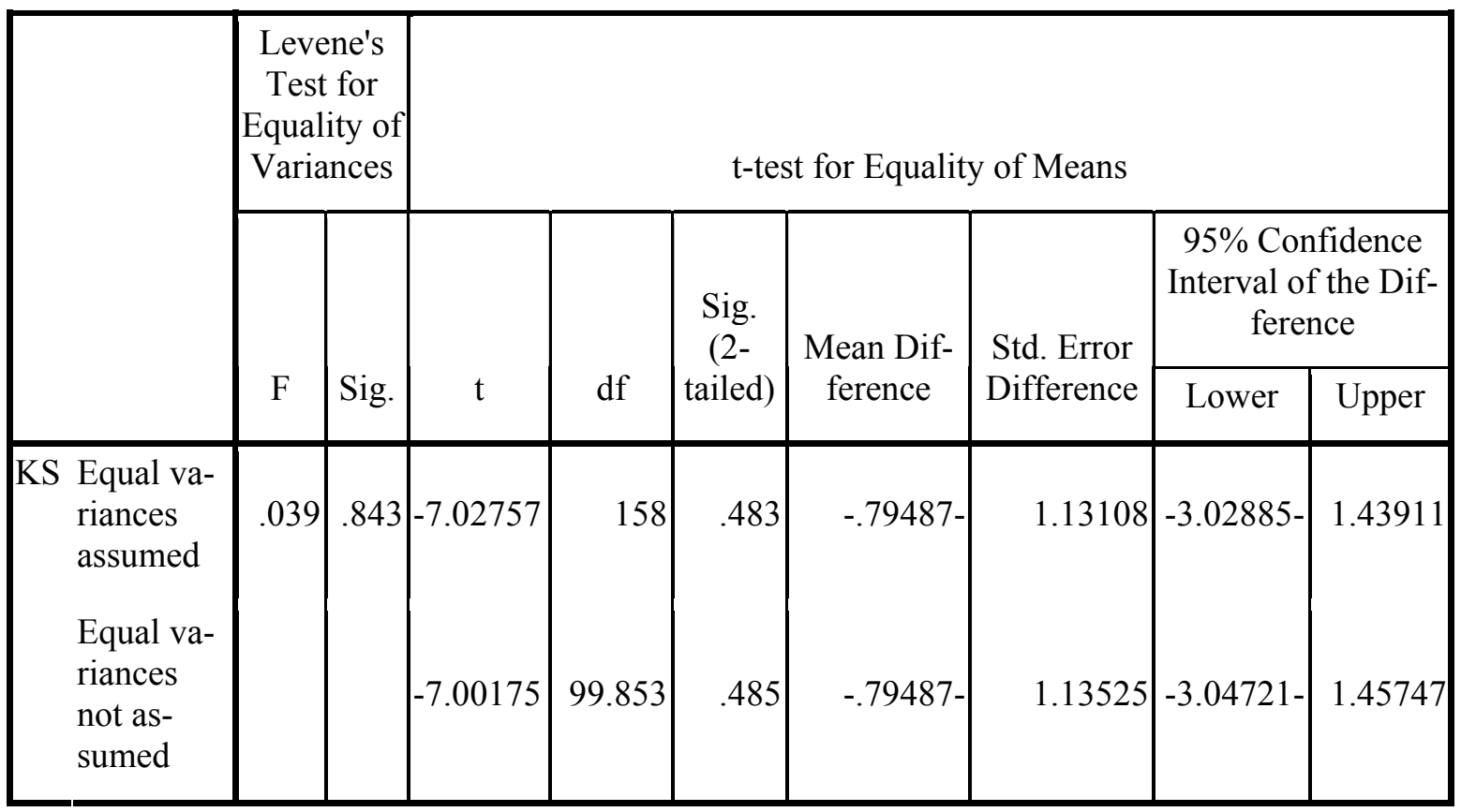

A One-Way ANOVA test was used to analyze if there are any differences in the evaluation of organizational knowledge sharing practices that can be attributed to the age and level of education. The results in Table 10 show both tests for age and level of education are not significant $(\mathrm{F}=$ 1.954 , with $\mathrm{P}-$ value $=.104)$ and $(\mathrm{F}=1.943$, with $\mathrm{P}$-value $=.106, \mathrm{P}>.05)$. Thus, we accept the null hypothesis that stated there are no differences in the evaluation of organizational knowledge sharing practices by Jordanian manufacturing managers that can be attributed to age or level of education. From the above data analysis a decision can be made toward accepting or rejecting the research hypothesis. Table 11 shows the hypotheses and decision of acceptance or rejection for research hypothesis. 
Table 10: One Way ANOVA for age and level of education

\begin{tabular}{|l|r|r|r|r|r|}
\hline \multicolumn{1}{|c|}{ Source } & \multicolumn{1}{|c|}{$\begin{array}{c}\text { Sum of } \\
\text { Squares }\end{array}$} & df & \multicolumn{1}{|c|}{$\begin{array}{c}\text { Mean } \\
\text { Square }\end{array}$} & F & Sig. \\
\hline \multicolumn{7}{|c|}{ Age } \\
Between Groups & 341.692 & 4 & 85.423 & 1.954 & .104 \\
Within Groups & 6775.408 & 155 & 43.712 & & \\
Total & 7117.100 & 159 & & & \\
\multicolumn{2}{|c|}{ Level of education } & & & & \\
Between groups & 339.763 & 4 & 84.941 & 1.943 & .106 \\
Within group & 6777.337 & 155 & 43.725 & & \\
Total & 7117.00 & 159 & & & \\
\hline
\end{tabular}

Table 11: Summary of research alternative hypothesis and decisions

\begin{tabular}{llc}
\hline Null Hypothesis & \multicolumn{1}{c}{ decision } \\
\hline $\begin{array}{l}\text { Hypothesis } \\
1\end{array}$ & knowledge sharing practices. & Rejected \\
\hline Hypothesis 2 & $\begin{array}{l}\text { H0: There is no relationship between organizational knowl- } \\
\text { edge sharing practices and employees' learning commit- } \\
\text { ments. }\end{array}$ & Rejected \\
\hline Hypothesis 3 & $\begin{array}{l}\text { H0: There is no relationship between organizational knowl- } \\
\text { edge sharing practices and employees' adaptability. }\end{array}$ & Rejected \\
\hline Hypothesis 4 & $\begin{array}{l}\text { H0: There is no relationship between organizational knowl- } \\
\text { edge sharing practices, employees' learning commitments, } \\
\text { employees' adaptability and job satisfaction. }\end{array}$ & Rejected \\
\hline Hypothesis 5 & $\begin{array}{l}\text { H0: There are differences in the evaluation of knowledge } \\
\text { sharing practices by employees that can be attributed to de- } \\
\text { mographic variables such as, gender, age, and level of educa- } \\
\text { tion. }\end{array}$ & jected \\
\hline
\end{tabular}

\section{Limitations and Practical implications}

Although this study has offered valuable insight into extant theories of knowledge sharing, it has some limitations that are common to questionnaire-based studies. First, even though this study focused on the listed manufacturing companies in Amman Stock Exchange, which represent to some extent a homogeneous population, the study did not take the company type and size into consideration. This may limit the generalizability of the results of this study to the listed manufacturing companies in Amman stock Exchange. Second, the stage of knowledge sharing elevates with the time span of organizational life and this study did not gain insight into how long the companies had been practicing knowledge sharing. Third, this study examined the relationship between knowledge sharing practices, employees' learning commitments, employees' adaptability, and employees' job satisfaction. In fact, a mutual relationship between the hypothesized constructs may exist (Becerra-Fernandez et al., 2004). In the literature, there are definitions for knowledge sharing that vary based on the purpose of research objectives. For validity purposes and to avoid any measurement errors, this study did not try to develop a comprehensive definition 
for knowledge sharing. Therefore, future research should develop a comprehensive definition to knowledge sharing in order to ensure consistent results regardless of the place and time of the study. Fourth, this study considers knowledge sharing as a broad concept without make a distinction between tacit and explicit knowledge sharing. Thus, we hope future studies will investigate the same research constructs but in a comparative manner between tacit and explicit forms. Fifth, the results of this study indicate there is no difference in the evaluation of organizational knowledge sharing practices in terms of demographic variables such as, gender, age, and level of education. Future research may choose take other organizational variables such as, organizational size, business strategy, organizational structure, task difficulties, and type of environment (stable or dynamic) into account. Sixth, although the manufacturing companies are interested to know more about the results of this study, they refuse to provide the researchers with a list that contains the employees' positions, which would allow follow-up interviews with some of the respondents.

Although this study was challenged by various limitations, it enriches knowledge-sharing literature and sheds light on the importance of knowledge sharing practices as a motivational factor for employees' learning commitments and employees' adaptability, which in turn relates to overall job satisfaction. Practically, this study provides a guide for practitioners on how knowledge sharing practices play a critical role in ensuring a quick and easy adjustment when business circumstances change unexpectedly. It also shows that effective and efficient job satisfaction can be achieved by a greater level of continuous learning and adaptability. In addition, this study draws the attention of Jordanian manufacturing managers toward the importance of ongoing learning processes to cope with environmental uncertainty caused by technological advancements and other cultural, social, political, and economical factors. Manufacturing managers are advised to consider blueprinting an effective training strategy that leverages employees' skills and knowledge on a continual basis. Manufacturing managers also can benefit from the results of this study by reducing employees level of stress, anxiety, turn over, and other similar undesirable factors that result from skill mismatch and job dissatisfaction (Vieira, 2005). Finally, this study highlights the importance of continuous employees learning and adaptability that is essential for an organization's innovativeness (Tuominen et al., 2004). It would be interesting to expand and examine the relationship between knowledge sharing, employees learning behavior, employees' adaptability, and organization innovativeness.

\section{Conclusions}

Our research makes conceptual, empirical, and managerial contributions to existing theories in knowledge sharing and knowledge management literature. On the conceptual side, we explain and clarify how knowledge sharing practices influence employees' adaptability, employees' learning commitments, and employee' knowledge sharing. We contribute to the conceptualization of knowledge sharing theories by constructing a theoretical model that links knowledge sharing practices, employees' learning commitments, employees' adaptability, and employees' job satisfaction. Unlike prior studies (Du et al. 2007; Hsu, 2008; Kameda \& Nakanishi, 2003; Law \& Ngai, 2008), this study makes direct links between knowledge sharing practices, employees' learning commitments, employees' adaptability, and employees' job satisfaction that presumably improve organizational performance. Thus, our research model will be useful for similar research that examines the antecedents of employees' learning commitments, employees' adaptability, and employees' job satisfaction.

Within the empirical dimension, our research findings showed that there is a significant relationship between knowledge sharing practices, employees' learning commitments, employees' adaptability, and employees' job satisfaction. Prior research has argued that knowledge management influences people, processes, products, and organizational performance. However, there is little known about how organizational knowledge sharing practices influence on people, such as em- 
ployees' learning commitments, employees' adaptability, and employees' job satisfaction. The data analysis indicates that Jordanian manufacturing managers perceived that their companies make use of organizational knowledge sharing practices. This result is in line with the results of (Hsu, 2008). Interestingly, the managers revealed that their organizations do not provide any monetary rewards for employees to increase their willingness to share their knowledge. This result may be interpreted as an educational issue with the manufacturing managers in this study who are not aware of - or do not believe in - the importance of monetary and non-monetary rewards to facilitate higher levels of knowledge sharing within organizations.

On the managerial side, various practical implications were directly provided and go beyond knowledge sharing practices to influence organization innovativeness. Overall, our data analysis highlights the importance of nurturing knowledge sharing in a manufacturing environment to ensure ongoing learning processes and a high level of adaptability, which in turn increases employee job satisfaction. If improvements in organizational performance are to take place, the interaction between knowledge sharing practices, employees' learning commitments, employees' adaptability, and employees' job satisfaction should be facilitated.

\section{References}

Bartol, K. M., \& Srivastava, A. (2002). Encouraging knowledge sharing: The role of organizational reward systems. Journal of Leadership and Organizational Studies, 9(1), 64-76.

Becerra-Fernandez, I., Gonzalez, A., \& Sabherwal, R. (2004). Knowledge management: Challenges, solution, and technologies. Upper Saddle River, NJ: Prentice -Hall.

Bock, G. W., \& Kim, Y. G. (2002). Breaking the myths of rewards. Informational Resources Management Journal, 15(2), 14-21.

Burke, C. S., Pierce, L. G., \& Salas, E. (Eds.) (2006). Understanding adaptability: A prerequisite for effective performance within complex environment. Advances in human performance and cognitive engineering research, vol. 6, (pp. 1-288). Retrieved 15 November 2009 from: http://books.google.com/books

Chiu, C., Hsu, M., \& Wang, E. (2006). Understanding knowledge sharing in virtual communities: An integration of social capital and social cognitive theories. Decision Support Systems, 42(3), 1872-1888.

Du, R., Ai, S., \& Ren, Y. (2007). Relationship between knowledge sharing and performance: A survey in Xi'an China. Expert systems with Applications, 32(1), 38-46.

Garfield, S. (2006). 10 reasons why people don't share their knowledge. Km Review, 9(2), $10-11$.

Georgsdottir, A., \& Getz, I.(2004). How flexibility facilitates innovation and ways to manage it in organizations. Creativity and Innovation Management, 13(3), 166-175.

Hair, J., Tatham, R., Black, W. Babin, B., \& Anderson, R. (2009). Multivariate data analysis (7th Ed.). Upper Saddle River, NJ: Prentice-Hall.

Hartline, M. D., \& Ferrell, O. C. (1996). The management of customer -contact service employees: An empirical investigation. Journal of Marketing, 60, 52-70.

Hesketh, B., \& Neal, A. (1999). Technology and performance. In D. R. IIgen \& E. D. Pulakos(Eds.), The changing nature of performance : Implications for staffing, motivations, and development (pp. 21-55), San Francisco: Jossy-Bass.

Hsu, I. (2006). Enhancing employees' tendencies to share knowledge - Case studies of nine companies in Taiwan. International Journal of Information Management, 26(4), 326-338.

Hsu, I. (2008). Knowledge sharing practices as a facilitating factor for improving organizational performance through human capital: A preliminary test. Expert Systems with Applications, 35(3), 1316-1326. 
Hsu, M., Ju, T., Yen, C., \& Chang, C. (2007). Knowledge sharing behavior in virtual communities: The relationship between trust, Self-efficacy, and outcome expectations. International Journal of HumanComputer Studies, 65(2), 153-169.

Hurley, R., \& Hult, G. (1998). Innovation, market orientation, and organizational learning: An integration and empirical examination. Journal of Marketing, 62, $42-54$.

Inkpen, A. C. (2000). Learning through joint ventures: A framework of knowledge acquisition. The Journal of Management Studies, 37(7), 1019-1043.

Kameda, T., \& Nakanishi, D. (2003) Does social/cultural learning increase human adaptability? Rogers's question revisited. Evolution and Human Behavior, 24, 242-260.

Karaevli, A., \& Hall, D.T (2006). How career variety promotes the adaptability of managers: A theoretical model. Journal of Vocational Behaviour, 69(3), 359-373.

Kearns, G., \& Lederer, A. (2003). A resource -Based view of strategic IT alignment: How knowledge sharing creates competitive advantage. Decision Sciences, 34(1), 1-29.

Kuo, F., \& Young, M. (2008). Predicting knowledge sharing practices through intention: A test of competing models. Computer in Human Behaviour, 24(6), 2697-2722.

Law, C. C. H. \& Ngai, E. W. T. (2008). An empirical study of the effects of knowledge sharing and learning behaviours on firm performance. Expert Systems with Applications: An International Journal, 34(4), 2342-2349.

Lee, D. J., \& Ahn, J. H. (2006). Reward systems for intra-organizational knowledge sharing. European Journal of Operational Research, 180(2), 938-956.

Lin, W. B. (2008). The effect of knowledge sharing model. Expert Systems with Applications: An International Journal, 34(2), 1508-1521.

Michailova, S., \& Husted, K. (2003). Knowledge-sharing hostility in Russian firms. California Management Review, 45(3), 59-77.

Moyers, P., \& Coleman, S. (2004). Adaptation of the older worker to occupational challenges. Work: A Journal of Prevention, Assessment, and Rehabilitation, IOS Press, 22(2), 71-78.

Murphy, P. R., \& Jackson, S. E. (1999). Managing work role performance: Challenges for twenty-first century organizations and their employees. In D. R. IIgen \& E. D.Pulakos (Eds.), The changing nature of performance:Iimplications for staffing, motivations, and development (pp. 325-365). San Francisco: Jossy-Bass.

Nonaka, I., (1991). The knowledge creating company. Harvard Business Review, 69(6), 96-104.

Park, J., \& Holloway, B. (2003). Adaptive selling behaviour revisited: An empirical examination of learning orientation, sales performance, and job satisfaction. Journal of Personal Selling \& Sales Management, 23(3), 239-251.

Parker, R. \& Kyj, L. (2006). Vertical information sharing in the budgeting process. Accounting, Organizations and Society, 31(1), 27- 45.

Paulsson, K., Ivergard, T., \& Hunt, B. (2005). Learning at work: Competence development or competencestress. Applied Ergonomics, 36(2), 135-144.

Ployhart, R. E., \& Bliese, P. D. (2006). Individual adaptability (I-ADAPT) theory: Conceptualizing the antecedents, consequences, and measurement of individual differences in adaptability. In C. S. Burke, L. G. Pierce, \& E.Salas (Eds), Understanding adaptability: Prerequisite for effective performance within complex environments, Advances in Human Performance and Cognitive Engineering Research, (Volume 6, pp. 3-39). Emerald Group Publishing.

Pulakos, E., Arad, S., Donovan, M., \& Plamondon, K. (2000). Adaptability in the workplace: Development of a taxonomy of adaptive performance. Journal of Applied Psychology, 85(4), 612-624. 
Pulakos, E. D., Dorsey, D. W., \& White, S. S. (2006). Adaptability in the workplace: Selecting an adaptive workforce. In C. S. Burke, L. G. Pierce, \& E.Salas (Eds), Understanding adaptability: Prerequisite for effective performance within complex environments, Advances in Human Performance and Cognitive Engineering Research, (Volume 6, pp. 41-71). Emerald Group Publishing.

Rowley, J. (2000). From learning organisation to knowledge entrepreneur. Journal of Knowledge Management, 4(1), 7-15.

Savickas, M. L. (2005). The theory and practice of career construction. In S. D.Brown \& R. W. Lent (Eds.), Career development and counseling: Putting theory and research to work (pp. 42-70). Hoboken, NJ: Wiley.

Sherehiy, B., Karawowski, W., \& Layer, J. (2007). A review of enterprise agility: Concepts, frameworks, and attributes. International Journal of Industrial Economics, 37, 445-460.

Siemsen, E., Roth, A. V., \& Balasubramanian, S. (2008). How motivation, opportunity, and ability drive knowledge sharing: The constraining -factor model. Journal of Operations Management, 26, 426-445.

Tsai, P., Yen, Y., Huang, L.C., \& Huang, I.C. (2007). A study on motivating employees' learning commitment in the post-downsizing era: Job satisfaction perspective. Journal of World Business, 42(2), 157169.

Tuominen, M., Rajala, A., \& Moller, K. (2004). How does adaptability drive firm innovativeness? Journal of Business Research, 57, 495-506.

Vieira, J. A. C. (2005). Skills mismatch and job satisfaction. Economics Letters, 89, 39-47.

Yang, J. T. (2007). Knowledge sharing: Investigating appropriate leadership roles and collaborative culture. Tourism Management, 28(2), 530-543.

Yang, J. T. (2008). Individual attitudes and organizational knowledge sharing. Tourism Management, 29(2), 345-353.

Yang, J. T. (2009). Antecedents and consequences of job satisfaction in the hotel industry. International Journal of Hospitality Management, 1-11. doi:10.1016/j.ijhm.2009.11.002.

Zahra, S. A., Neubaum, D. O., \& Larrañeta, B. (2007). Knowledge sharing and technological capabilities: The moderating role of family involvement. Journal of Business Research, 60(10), 1070-1079. 


\section{Appendix}

\section{Questionnaire Survey items}

\section{PART 1: GENERAL Background}

This section is concerned with your background. This information will help identify varying trends in responses for different groups of managers. Please remember that your responses are completely ANONYMOUS.

Name of Respondent:

Gender of respondent:
Age of respondent:

Respondent level of education:

\section{PART 2: Organisational knowledge sharing practices}

This section is concerned with investigating knowledge sharing practices. Please insert an $\mathbf{X}$ in the appropriate column. The options range from 1(strongly disagree), 2(disagree), 3(neither disagree nor agree), 4 (agree), and 5 (strongly agree).

\begin{tabular}{|c|c|c|c|c|c|c|}
\hline \multicolumn{2}{|r|}{ Organisational Knowledge sharing practices } & \multicolumn{2}{|c|}{$\begin{array}{l}\text { Strongly } \\
\text { Disagree }\end{array}$} & \multicolumn{3}{|c|}{$\begin{array}{c}\text { Strongly } \\
\text { Agree }\end{array}$} \\
\hline & & 1 & 2 & 3 & 4 & 5 \\
\hline Q1 & $\begin{array}{l}\text { My company uses senior personnel to mentor junior em- } \\
\text { ployees. }\end{array}$ & & & & & \\
\hline $\mathbf{Q 2}$ & My company groups employees in work teams. & & & & & \\
\hline Q3 & $\begin{array}{l}\text { My company analyzes its past failures and disseminates } \\
\text { lessons learned among its employees. }\end{array}$ & & & & & \\
\hline Q4 & $\begin{array}{l}\text { My company invests in IT systems that facilitate knowl- } \\
\text { edge sharing. }\end{array}$ & & & & & \\
\hline Q5 & My company develops knowledge sharing mechanisms. & & & & & \\
\hline Q6 & $\begin{array}{l}\text { My company offers incentives to encourage knowledge } \\
\text { sharing. }\end{array}$ & & & & & \\
\hline Q7 & $\begin{array}{l}\text { My company offers a variety of training and development } \\
\text { programs. }\end{array}$ & & & & & \\
\hline
\end{tabular}




\section{PART 3: employees' learning commitments}

This section is concerned with investigating the employees' learning commitments. Please insert an $\mathbf{X}$ in the appropriate column. The options range from 1(strongly disagree), 2(disagree), 3(neither disagree nor agree), 4 (agree), and 5 (strongly agree).

\begin{tabular}{|c|c|c|c|c|c|c|}
\hline \multicolumn{2}{|c|}{ Learning commitment } & \multicolumn{3}{|c|}{$\begin{array}{l}\text { Strongly } \\
\text { Disagree }\end{array}$} & \multicolumn{2}{|c|}{$\begin{array}{l}\text { Strongly } \\
\text { Agree }\end{array}$} \\
\hline & & 1 & 2 & 3 & 4 & 5 \\
\hline Q8 & $\begin{array}{l}\text { I am willing to spend extra time taking part in the internal } \\
\text { and external training courses provided by the firm. }\end{array}$ & & & & & \\
\hline Q9 & $\begin{array}{l}\text { I am eager to learn more specific knowledge and skills to } \\
\text { achieve job goals. }\end{array}$ & & & & & \\
\hline Q10 & $\begin{array}{l}\text { I believe that all the learning opportunities are advanta- } \\
\text { geous to me. }\end{array}$ & & & & & \\
\hline Q11 & $\begin{array}{l}\text { I believe that all learning opportunities are advantageous } \\
\text { to the firm. }\end{array}$ & & & & & \\
\hline Q12 & To me, being able to learn constantly is very important. & & & & & \\
\hline
\end{tabular}

\section{PART 4: Employees’ adaptability}

This section is concerned with investigating the employees' adaptability. Employees' adaptability includes the following dimensions (Crises adaptability, Cultural adaptability, physical work adaptability, Uncertainty adaptability, Creativity adaptability, Interpersonal adaptability, Work stress adaptability, and Learning adaptability). Please insert an $\mathbf{X}$ in the appropriate column. The options range from 1 (strongly disagree), 2(disagree), 3(neither disagree nor agree), 4 (agree), and 5 (strongly agree).

\begin{tabular}{|c|c|c|c|c|c|c|}
\hline \multirow{2}{*}{\multicolumn{2}{|c|}{ Crisis adaptability }} & \multicolumn{2}{|c|}{$\begin{array}{l}\text { Strongly } \\
\text { Disagree }\end{array}$} & \multicolumn{3}{|c|}{$\begin{array}{l}\text { Strongly } \\
\text { Agree }\end{array}$} \\
\hline & & 1 & 2 & 3 & 4 & 5 \\
\hline Q13 & I am able to maintain focus during emergencies. & & & & & \\
\hline Q14 & In an emergency situation, I stand aside. & & & & & \\
\hline Q15 & I think clearly in times of emergency. & & & & & \\
\hline Q16 & I am able to be objective during emergencies. & & & & & \\
\hline Q17 & I usually step up and take action during a crisis. & & & & & \\
\hline Q18 & I make excellent decisions in times of crisis. & & & & & \\
\hline Q19 & $\begin{array}{l}\text { In an emergency situation, I can put aside my emotional } \\
\text { feeling to handle important tasks. }\end{array}$ & & & & & \\
\hline
\end{tabular}




\begin{tabular}{|c|c|c|c|c|c|c|}
\hline \multicolumn{2}{|c|}{ Cultural adaptability } & \multicolumn{3}{|c|}{$\begin{array}{l}\text { Strongly } \\
\text { Disagree }\end{array}$} & \multicolumn{2}{|c|}{$\begin{array}{l}\text { Strongly } \\
\text { Agree }\end{array}$} \\
\hline & & 1 & 2 & 3 & 4 & 5 \\
\hline Q20 & I enjoy learning about cultures other than my own. & & & & & \\
\hline Q21 & I work well with others from different cultures. & & & & & \\
\hline Q22 & It is important to me that I respect other cultures. & & & & & \\
\hline Q23 & $\begin{array}{l}\text { I enjoy the variety and learning experiences that come } \\
\text { from working with people of different backgrounds. }\end{array}$ & & & & & \\
\hline Q24 & $\begin{array}{l}\text { I feel comfortable interacting with others who have dif- } \\
\text { ferent values and customs. }\end{array}$ & & & & & \\
\hline
\end{tabular}

\begin{tabular}{|c|c|c|c|c|c|c|}
\hline \multirow{2}{*}{\multicolumn{2}{|c|}{ Physical work adaptability }} & \multicolumn{3}{|c|}{$\begin{array}{l}\text { Strongly } \\
\text { Disagree }\end{array}$} & \multicolumn{2}{|c|}{$\begin{array}{l}\text { Strongly } \\
\text { Agree }\end{array}$} \\
\hline & & \multirow{2}{*}{1} & \multirow[t]{2}{*}{2} & \multirow{2}{*}{3} & \multirow[t]{2}{*}{4} & \multirow[t]{2}{*}{5} \\
\hline $\mathbf{Q 2 5}$ & I can only work in an orderly environment. & & & & & \\
\hline Q26 & $\begin{array}{l}\text { If my environment is not comfortable (e.g. cleanliness), I } \\
\text { cannot perform well. }\end{array}$ & & & & & \\
\hline Q27 & $\begin{array}{l}\text { I would quit my job if it required me to be physically } \\
\text { stronger. }\end{array}$ & & & & & \\
\hline Q28 & I physically push myself to complete important tasks. & & & & & \\
\hline Q29 & I can work effectively even when I am tired. & & & & & \\
\hline Q30 & I cannot work well when it is too hot or cold. & & & & & \\
\hline Q31 & I keep working even when I am physically exhausted. & & & & & \\
\hline Q32 & I utilize my muscular strength well. & & & & & \\
\hline Q33 & I am adept at using my body to complete relevant tasks. & & & & & \\
\hline
\end{tabular}




\begin{tabular}{|c|c|c|c|c|c|c|}
\hline \multirow{2}{*}{\multicolumn{2}{|c|}{ Uncertainty adaptability }} & \multicolumn{3}{|c|}{$\begin{array}{l}\text { Strongly } \\
\text { Disagree }\end{array}$} & \multicolumn{2}{|c|}{$\begin{array}{l}\text { Strongly } \\
\text { Agree }\end{array}$} \\
\hline & & 1 & 2 & 3 & 4 & 5 \\
\hline Q34 & I need things to be "black and white". & & & & & \\
\hline Q35 & I become frustrated when things are unpredictable. & & & & & \\
\hline Q36 & $\begin{array}{l}\text { I am able to make effective decisions without all relevant } \\
\text { information. }\end{array}$ & & & & & \\
\hline Q37 & $\begin{array}{l}\text { I tend to perform best in stable situations and environ- } \\
\text { ments. }\end{array}$ & & & & & \\
\hline Q38 & $\begin{array}{l}\text { When something unexpected happens, I readily change } \\
\text { gears in response. }\end{array}$ & & & & & \\
\hline Q39 & I can adapt to changing situations. & & & & & \\
\hline Q40 & I perform well in uncertain situations. & & & & & \\
\hline Q41 & I easily respond to changing conditions. & & & & & \\
\hline$\overline{Q 42}$ & I can adjust my plan to changing conditions. & & & & & \\
\hline
\end{tabular}

\begin{tabular}{|c|c|c|c|c|c|c|}
\hline \multicolumn{2}{|c|}{ Creativity adaptability } & \multicolumn{3}{|c|}{$\begin{array}{l}\text { Strongly } \\
\text { Disagree }\end{array}$} & \multicolumn{2}{|c|}{$\begin{array}{l}\text { Strongly } \\
\text { Agree }\end{array}$} \\
\hline & & 1 & 2 & 3 & 4 & 5 \\
\hline Q43 & I am an innovative person. & & & & & \\
\hline Q44 & I am able to look at problems from a multitude of angles. & & & & & \\
\hline Q45 & $\begin{array}{l}\text { When resources are insufficient, I thrive on developing } \\
\text { innovation solutions. }\end{array}$ & & & & & \\
\hline Q46 & $\begin{array}{l}\text { I see connections between seemingly unrelated informa- } \\
\text { tion. }\end{array}$ & & & & & \\
\hline Q47 & $\begin{array}{l}\text { I am good at developing unique analyses for complex } \\
\text { problems. }\end{array}$ & & & & & \\
\hline
\end{tabular}




\begin{tabular}{|c|c|c|c|c|c|c|}
\hline \multirow{2}{*}{\multicolumn{2}{|c|}{ Interpersonal adaptability }} & \multicolumn{3}{|c|}{$\begin{array}{l}\text { Strongly } \\
\text { Disagree }\end{array}$} & \multicolumn{2}{|c|}{$\begin{array}{l}\text { Strongly } \\
\text { Agree }\end{array}$} \\
\hline & & 1 & 2 & 3 & 4 & 5 \\
\hline Q48 & I am an open- minded person in dealing with others. & & & & & \\
\hline Q49 & $\begin{array}{l}\text { I believe it is important to be flexible in dealing with oth- } \\
\text { ers. }\end{array}$ & & & & & \\
\hline Q50 & $\begin{array}{l}\text { I am perceptive of others and use that knowledge in inter- } \\
\text { actions. }\end{array}$ & & & & & \\
\hline Q51 & I try to be flexible when dealing with others. & & & & & \\
\hline Q52 & I adapt my behavior to get along with others. & & & & & \\
\hline Q53 & $\begin{array}{l}\text { I tend to be able to read others and understand how they } \\
\text { are feeling at any particular moment. }\end{array}$ & & & & & \\
\hline Q54 & My insights help me to work effectively with others. & & & & & \\
\hline
\end{tabular}

\begin{tabular}{|l|l|l|l|l|l|l|}
\hline \multirow{2}{*}{ Work stress adaptability } & \multicolumn{3}{|l|}{$\begin{array}{l}\text { Strongly } \\
\text { Disagree }\end{array}$} & \multicolumn{3}{|c|}{$\begin{array}{l}\text { Strongly } \\
\text { Agree }\end{array}$} \\
\hline & Q55 & I usually over-react to stressful news. & 2 & 3 & 4 & 5 \\
\hline Q56 & I feel unequipped to deal with too much stress. & & & & \\
\hline Q57 & I am usually stressed when I have a large workload. & & & & & \\
\hline Q58 & $\begin{array}{l}\text { I often cry or get angry when I am under a great deal of } \\
\text { stress. }\end{array}$ & & & & & \\
\hline Q59 & I am easily rattled when my schedule is too full. & & & & & \\
\hline
\end{tabular}


Relationships among Organizational Knowledge Sharing Practices

\begin{tabular}{|c|c|c|c|c|c|c|}
\hline \multicolumn{2}{|c|}{ Learning adaptability } & \multicolumn{3}{|c|}{$\begin{array}{l}\text { Strongly } \\
\text { Disagree }\end{array}$} & \multicolumn{2}{|c|}{$\begin{array}{l}\text { Strongly } \\
\text { Agree }\end{array}$} \\
\hline & & 1 & 2 & 3 & 4 & 5 \\
\hline Q60 & I take action to improve work performance deficiencies. & & & & & \\
\hline Q61 & $\begin{array}{l}\text { I often learn new information and skills to stay at the fo- } \\
\text { refront of my profession. }\end{array}$ & & & & & \\
\hline Q62 & I quickly learn new methods to solve problems. & & & & & \\
\hline Q63 & I trained to keep my skills and knowledge current. & & & & & \\
\hline Q64 & I am continually learning new skills for my job. & & & & & \\
\hline Q65 & I take responsibility for staying current in my profession. & & & & & \\
\hline Q66 & I try to learn skills for my job before they are needed. & & & & & \\
\hline Q67 & I enjoy learning new approaches for conducting work. & & & & & \\
\hline Q68 & I take responsibility for acquiring new skills. & & & & & \\
\hline
\end{tabular}




\section{PART 5: Employees' job satisfaction}

This section is concerned with investigating employee's job satisfaction. Please insert an $\mathbf{X}$ in the appropriate column. The options range from 1 (strongly disagree), 2(disagree), 3(neither disagree nor agree), 4 (agree), and 5 (strongly agree).

\begin{tabular}{|c|c|c|c|c|c|c|}
\hline \multirow{2}{*}{\multicolumn{2}{|c|}{ Employees' job satisfaction }} & \multicolumn{2}{|c|}{$\begin{array}{l}\text { Strongly } \\
\text { Disagree }\end{array}$} & \multicolumn{3}{|c|}{$\begin{array}{l}\text { Strongly } \\
\text { Agree }\end{array}$} \\
\hline & & 1 & 2 & 3 & 4 & 5 \\
\hline Q69 & My interests are compatible with the organization. & & & & & \\
\hline Q70 & I have the opportunity to apply my personal expertise. & & & & & \\
\hline Q71 & I am satisfied with my relationship with colleagues. & & & & & \\
\hline Q72 & I am satisfied with my chances for promotion. & & & & & \\
\hline Q73 & I am satisfied with my learning opportunities. & & & & & \\
\hline Q74 & I am satisfied with my job reputation. & & & & & \\
\hline Q75 & I am satisfied with my pay and bonus. & & & & & \\
\hline Q76 & I am satisfied with my job security. & & & & & \\
\hline Q77 & $\begin{array}{l}\text { I am satisfied with my working environment (including } \\
\text { location, security, and sanitation). }\end{array}$ & & & & & \\
\hline Q78 & I am satisfied with my director's leadership. & & & & & \\
\hline Q79 & I am satisfied with my job performance. & & & & & \\
\hline Q80 & $\begin{array}{l}\text { I am satisfied with the company's concern for my welfare } \\
\text { and life balance. }\end{array}$ & & & & & \\
\hline Q81 & I am content in my job. & & & & & \\
\hline
\end{tabular}

\section{Biographies}

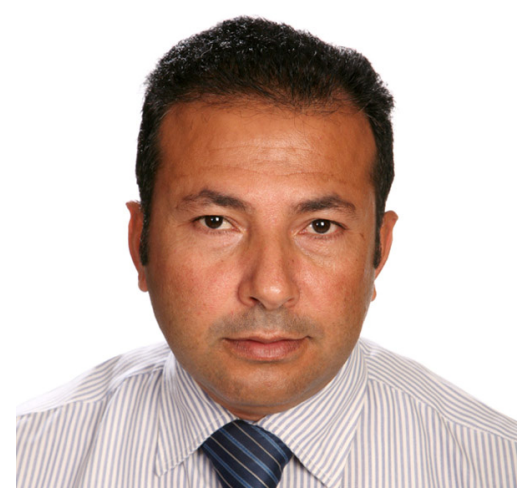

Dr. Soud Almahamid earned his doctorate in Management Information Systems at the University of the West of England /UK. He is currently a senior lecturer in faculty of Business Administration and Economics. He lectures on knowledge management, e-business, and e-government at the both gradugraduate and postgraduate levels. His main research lines are knowledge management, knowledge sharing, agility, ebusiness applications and e-services quality, and egovernment. He has presented a number of papers at national and international level conferences $\mathrm{He}$ has also authored numerous publications in national and international journals. 
Almahamid worked as a head of Business Administration Department since 16/9/2007 till 15/9/2008 and he served as a Vice-Dean of Business Administration and Economic Faculty at Al Hussein Bin Talal University from 16/9/2008 till 22/6/2009. Almahamid is the corresponding author and can be contacted on the e-mail below.soud.almahamid@ahu.edu.jo

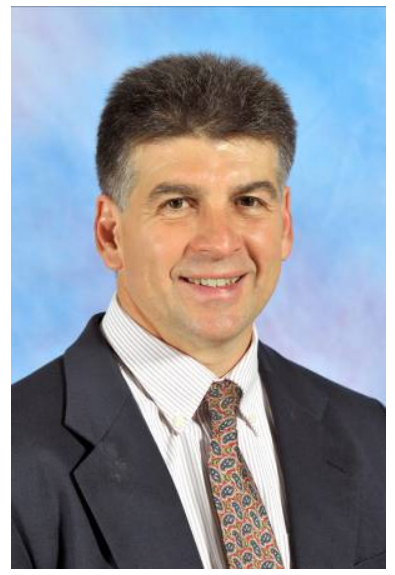

Dr. Arthur C. McAdams is a senior lecturer in the management department within the School of Business at the University of Bridgeport. $\mathrm{He}$ is also an adjunct professor in the Charles F. Dolan School of Business at Fairfield University, where he has taught management and ISrelated courses since 1999, and an independent management consultant. His expertise and interests are in strategy, operations management, and information systems. A former senior vice president at People's Bank, Dr. McAdams is an accomplished executive with more than 30 years of progressive experience in systems development, project and process management, business planning, and general management. McAdams joined People's Bank in 1984 as a project leader, and was ultimately named director of Information Systems in 1994, where he led the successful implementation of several strategic initiatives. Prior to joining People's, he worked as a computer programmer/analyst at Pitney Bowes Inc. McAdams has written articles published in The Association for Computer Information Systems, The Journal of Technology, Knowledge, and Society, and The Information Management Journal. He has also served as a guest lecturer at local universities, corporate educator, and a speaker at national conferences on a variety of subjects. Dr. McAdams holds a B.S. in General Studies from Fairfield University, an MBA from the University of Connecticut, and a Ph.D. in Information Systems from Nova Southeastern University.

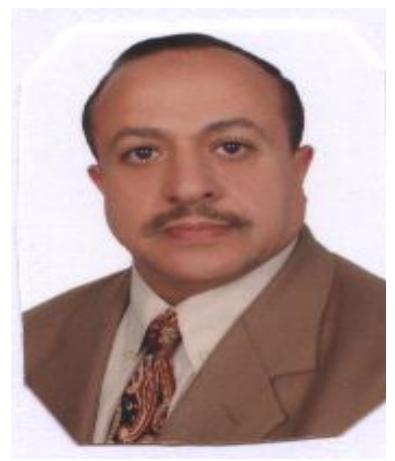

Dr. Taher Al kalaldeh is an assistant professor specialized in the $\mathrm{Hu}-$ man Resources Management. Al kalaldeh holds many credentials contribute in developing the essence of human resources management in Jordan. He has plenty memberships in different disciplines, beside he has been granted many degrees of "Expert" from national and international institutions based on his enormous activities in developing and expanding that area of business administration. He is also granted a degree of "Consultant" for many training programs concerned with leadership and administration, training and development, and motivating productivity. Recently, the second edition of his book "developing and managing the human recourses" has been launched to be the main academic reference in many institutions inside and outside Jordan, in addition to a considerable number of research was published in several local and international journals. Finally, he is looking for establishing a foundation for human resources in Jordan as it is a new concept has emerged and evolved recently within Jordanian organizational structures. 